\title{
JOURNAL.RU
}

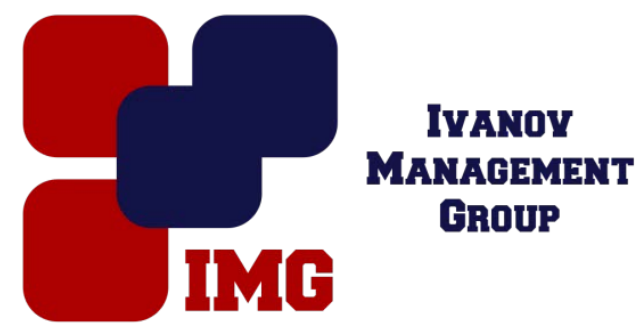

Andreeva S.M.,BezuglovaO.V., Andreeva A.M. Belgorod State University of Arts and Culture

Belgorod, Russia

doi: 10.18411/lj-25-12-2016-2-06

idsp 000001:lj-25-12-2016-2-06

\section{Pre-university training of foreign students}

\begin{abstract}
Preparatory Faculties for foreign citizens play a key role in the development of training systems for foreign countries in the universities of our country. In addition to its special functions for training and social integration of foreign citizens, in most cases, they represent centers at universities, which concentrate all the work on the organization of the reception and training of foreign students. In addition, the development of training systems for foreign countries in Russian universities, in general, depends on the fact, how successful will be organized training activities of foreigners in these structural units.

Keywords: Preparatory Faculties for foreign citizens, methods of education, specialist, pre-university training, higher education.

In modern conditions by granting greater autonomy to universities, in the absence of rigid centralization of control by the Ministry of Education and exhaustive aspiration to improve the financial situation of universities by attracting extrabudgetary sources of financing, including through training of foreign nationals, quality of education and its corresponding control by the state become crucial issues.

Solution of these issues is possible through certain policies on the basis of theoretical study and practical operation of the flexible subsystem of pedagogical additional training of foreign nationals.

All the foregoing involves the following problems and issues:

- It is required the organization and conduct of testing of foreign citizens in the homeland for general scientific disciplines in order to detect compliance of the real level of the candidate to requirements of Russian higher education.

- Market Marketing of educational services is required to determine the most popular specialties, the required level of education (undergraduate, graduate, postgraduate), the determination of quantitative and qualitative characteristics of the population.

- Allocation of priorities across countries and regions is due to, firstly, political interests of the State and, secondly, the analysis of the level of general education of potential foreign students.
\end{abstract}


- The requirements in accordance with the training profiles - in accordance with the standard, depending on the profile of training there were defined mandatory subjects and requirements for the level of knowledge on these disciplines, set the number of academic hours for each discipline; It was recommended the additional and optional disciplines at the discretion of the Faculty Board.

- The requirements for the disciplines - the application to the standard include recommendations on the presentation of the main issues of courses which determine the level of requirements, depending on the profile of training, give the departments the ability to adjust teaching hours, determine a list of laboratory works, colloquiums.

- Training and work plans developed as a supplement to the industry standard; they provide input of academic subjects each week, the distribution of the number of hours for each profile of education and timing of the training, contain recommendations for variation plans in accordance with the features of the Faculty.

- Developing, publishing and using of teaching materials - organization of educational process at the stage of pre-university education requires the use of special teaching aids in the Russian language, scientific style of speech, aids for the initial phase of the scientific disciplines, development of dictionaries with translation into the languages of intermediaries and national languages and other.

- Requirements for teachers - the specificity of the learning process of foreign citizens at the stage of pre-university education makes additional demands on teachers. This is primarily knowledge of related disciplines, foreign language, the opportunity to teach Russian as a foreign language.

- The right to issue the certificate of the state sample may be granted to educational structures on the basis of their certification.

- Visa support includes official invitation and obtaining an entry-exit visa for education, obtaining the registration of residence, drawing up visa documents for departure to other countries and to their homeland, etc.

- The status of foreign student is defined by obligations of sending and receiving parties, contractual obligations of students, the legislative acts defining the stay of foreign citizens in Russia.

- Medical Service provides initial medical examination (on arrival), health insurance coverage, and medical treatment.

- Living conditions include registration and provision of dormitories for the accommodation during the entire period of study.

The training level requirements define the foundation to quality of higher professional education. There are significant differences between school training in Russia and other countries.These differences are not only in the content of the programs, but also in the method of construction of the courses, the quality and depth of acquired knowledge, development of common training and subject skills, individual abilities.Therefore particularly important question is the selection of foreign citizens wishing to study at Russian higher school for compliance with the level of training that provided by the Russian secondary school.Evaluation of the level of general education of foreign citizens is advantageously carried out with the use of testing on the basic disciplines, defining the profile of teaching in higher education. 
Testing allows you to determine to which class of the Russian secondary school in a certain subject corresponds the level of knowledge of a foreign citizen.It should be noted that the level of general education of foreign citizens correlates with final exams at the Faculty of pre-university training and further academic progress of study at the university.Diagnostic and prognostic value of the test depends on its scientific validity, of how the test was created: whether it is the result of much preliminary experimental work or whether it is simply the consequence of rough, random and surface observations.Well-constructed and conducted tests can be of great help in identifying the level of skills in this or that area.

If we choose test as a form of final control at the preparatory faculty, it is necessary to bear in mind that the main function of total control is fixing the state of knowledge of foreign students, fixing achievement or non-achievement of the level of knowledge and skills defined by some standards. The purpose of training at the Faculty of Pre-University Training - is a preparation for training at universities and, therefore, the test should reveal this readiness, therefore, it should be developed on the basis of the standard - requirements for the preparation of training at the preparatory faculty.

Another important component providing the functioning of the system of preuniversity training of foreign citizens is personnel support; in this case requirements for teachers and educational centers (departments) of preparatory training are of fundamental importance.

Features of work in a foreign audience at the level of pre-university training compared to the system of teaching in Russian higher education are as follows:

1) Embarking on training at the preparatory faculty foreign citizens do not speak Russian and are not familiar with the new conditions of education and everyday life, so the first year in the Russian Federation, attributable to the pre-university education, is a period of adaptation.

2) Study groups, in which the teacher's work is held, are small: 6-8 people - a group for the Russian language classes, 14-16 people - a group for all other disciplines.

3) Within a relatively small-sized groups there can be foreign students with different levels of knowledge (sometimes significantly), received in the homeland, and from the various countries and regions.

4) Department of preliminary training or other similar educational center represents a closed homogeneous system, i.e. teaching staff works mostly with foreign students, and they, in their turn, communicate only with the teaching staff.

5) The purpose of education at the preparatory faculty is to provide for graduates of the knowledge and skills in the Russian language and other disciplines (depending on the profile of training), and a high degree of social adaptation, which would enable foreign students to perceive successfully the training program in the first year of a Russian university education [7, pp.67-69].

Therefore, the qualification requirements for a teacher at the stage of preuniversity training of foreign citizens, except conventional for the university lecturer, include some specific qualities.

Faculty members and pre-university training centers, depending on the subjects taught, can be divided into three main groups:

- Teachers of Russian (Russian language, literature, scientific style of speech) 
- Teachers of General Scientific Disciplines (mathematics, physics, chemistry, biology, computer science, engineering graphics, etc.)

- Teachers social and humanitarian disciplines (Country Study, history, geography, economics, etc.).

Regardless of the taught discipline, teachers should:

- Possess knowledge in the taught discipline within the program at a high professional level, and in a broader context, for the necessary coordination of teaching at the faculty and the student's homeland, on the one hand, as well as at the faculty and during the first year of the university on the other hand;

- Be able to create a favorable working climate in a heterogeneous group and to provide an individual approach to learning;

- Possess information about those countries and regions from which foreign students arrived, about the level of education and links of the Russian Federation with these countries and regions;

- Be cognizant of other disciplines taught in the group, since during the initial training period any teacher in the eyes of foreign students is not only a carrier of information in a particular area, but also a person who represents the faculty as a whole;

- Be prepared to provide international students with assistance in solving a variety of problems associated with their adaptation in the first stage, and have the needed information,

In addition to these general questions the teacher must meet the requirements associated with the taught discipline.Russian language teachers are obliged to have a specialization of "teaching Russian as a foreign language" or to pass courses of professional skills improvement, as well as to possess the methodology of teaching scientific style of speech as an aspect of training;possession of methodology of scientific style of speech implies the awareness of the teacher of the Russian language in the field of general scientific and social-humanitarian disciplines, depending on the profile of training. As a rule, Russian language teachers have to speak a foreign language. In addition, at the Department there should be teachers of literature to provide training in groups of a humanitarian profile.

Teachers of General Scientific Disciplines conduct lessons with students in Russian, so the specifics of teaching in this group of subjects is the teaching of a particular discipline in Russian as a foreign language; possession of this technique, as well as the introduction of elements of Scientific style of speech at the initial stage is a prerequisite for successful work with foreign audiences. Also, knowledge of a foreign language is desirable to assist international students during the period of stay in Russia, for the translation of texts and tasks, for extracurricular communication. As every year the contingent of foreign students varies, and the distribution of students by profiles every year is unevenly, the positive factor is the possibility of a teacher to teach in related disciplines within the department.

The system of improvement of professional training of teachers, in accordance with the requirements listed above, includes:

- Training at specialized faculties of professional development;

- Training at related departments;

- Participation in specialized seminars on the exchange of experiences of teachers of pre-university training;

- Interdepartmental mutual exchange of experience within the same faculty;

- Consultations, seminars, mutual attending classes within the department and the faculty.

At this level of organizational and management ensure of preparatory training of foreign nationals Educational Institution - Pre-University Training Faculty solves such 
problems as: formation of a contingent of students; admission of foreign citizens for training; their settlement in a dormitory; paperwork; organization of educational process (acquisition of groups, scheduling, organizing of examination sessions):graduation of foreign students and issue certificates of completion of training; assistance to students in their allocation for further training; assistance to foreign students in the solution of social problems and health care issues. Hence we can see the hard everyday contact of the deanery and the departments and constant meticulous coordination of organizational and methodical work. Therefore the faculty is like a "state within a state", as it has broader responsibilities and certain specificity [7, pp 70-72].

Types of academic work at the preparatory faculty are consistent with those taken in high school.At the same time the educational process has a number of specific features that are defined by the tasks of training and the contingent of foreign nationals. The training is conducted on the basis of the curriculum on the corresponding profile. At the same time phased commissioning of academic subjects is provided in each plan. For example, for engineers and technicians, starting with the 3rd week of teaching the Russian language, it begins the teaching of general theoretical disciplines in the following sequence: drawing, mathematics, chemistry, physics, from the 11th week it is added informatics. Examination sessions shall be held twice, respectively in JanuaryFebruary and June-July. In case of late arrival of students (till December), the learning process is shifted to the summer months - June and July, respectively, and examination session for the second half of August, resits is carried out only after the spring session.

The teachers of the Russian language department work throughout the year with one group (the group of 6-8 people).The first training period requires from the teacher especially great emotional and physical costs in connection with the lessons of phonetics (4-6 hours per day of difficult "throat" work, 5-6 days a week), due to the need to use non-verbal methods of explanation, because the group is often staffed by students from different regions and to use one intermediate language is not possible. The formation of groups on the basis of intermediate language is hampered by the arrival at different dates and different training profiles. indefinite period of time of students' arrival also leads to the fact that initially the group consists of 3-4 students, and then its composition can be brought up to 6-8 people, so the teacher has to "adjust" latecomers additionally. Since the teaching of the Russian language includes two aspects - of General style of speech and scientific style of speech, then in groups of different profiles scientific style of speech is focused on the future specialty of foreign nationals.

Teachers of the department of general theoretical subjects conduct lectures and practical classes in groups where the number of foreign students is usually 12-14 people, the group usually includes students from various regions with different basic training of the various national schools. These circumstances determine specific, inherent only to this group, situation that demands from the teacher of individual methodological approaches and development of training materials aimed only at this part of foreign students. As a teacher conducts classes in several significantly different in many respects groups, the efforts of the teacher, spent for maintenance of educational process, increase significantly.In many cases, basic training, received by foreign students in homeland, is much lower than necessary, and filling any gaps in the relatively short term of study requires maximum intensification of the educational process.One of the most important moments of organizational and management support system of pre-university training of foreign nationals is interdisciplinary coordination and continuity between the departments in teaching at the Faculty of Pre-University Training. 
The teachers of the Russian language carry out targeted training of foreign students of the scientific style of speech on the basis of the material of general theoretical subjects and social sciences, which includes educational, scientific and socio-political language and the most common constructions.The teachers of general theoretical subjects (mathematics, physics and others) should pay attention not only to the assimilation of subject matter, but also to correctness of the grammatical processing of speech utterances of foreign students and the formation of the main types of speech activity on the material of the subject.

In the work of preparatory departments of the Faculty its coordination takes a special place due to the specific characteristics of the faculty.These features are related, on the one hand, with a fairly rigid terms of training and with a significant amount of educational information in the Russian language and other subjects, and on the other hand, with the need to teach of general theoretical cycle of subjects in Russian and a foreign language if there is sufficiently early introduction of subjects in the learning process.In comparison with the work of the departments of general educational disciplines on the basic faculties the feature of the work of the preparatory faculty is the closed educational process with the limited contingent of foreign students.All these factors lead to the need for coordination in the teaching of all disciplines at the preparatory faculty.

One of the most important problems is the problem of optimization and intensification of educational process for foreign students. In working on this issue we can distinguish the following activities:

- coordination of intersubject communications of disciplines for foreign students, the creation of integrated training courses and programs;

- individualization of the learning process, which allows to consider national, personal characteristics of the student, his level of education, and on this basis to build a learning process in the most efficient way;

- implementation of modern education programs, textbooks and scientific and methodological developments in the learning process;

- extensive use of modern means of training, that is especially effective in language learning.

In this regard, an important factor, that has a huge impact on the modernization and reform of Russian higher education, is a so-called Bologna process.The aim of this process is the creation of "European Higher Education Area", where national identities and common interests can interact and strengthen each other for the benefit of Europe, its students, and more generally - citizens.Russia joined the Bologna process in 2003. The result of this should be the compliance of the Russian education to generally accepted international standards. In our opinion, it is much easier entry of Russia into the international educational space, including the sphere of training of specialists for foreign countries.

Thus foreign students studying in Russian universities at faculties of preliminary training should strive to:

- learn the general course of the Russian language;

- learn the scientific style of speech;

- restore the knowledge of, skills and abilities in the profile subjects;

- gain new knowledge and skills that make the difference between a Russian school programs and the previous program in the country of study;

- extend and deepen knowledge of the school to the level at which teaching in higher education is based;

- develop individual learning ability; 
- acquire and develop the skills of educational work, inherent in Russian higher education (self-study, listening and note-taking lectures, work with books, lab work, etc.);

- adapt to the regime of study;

- adapt to the climate and social conditions;

- adapt to the cultural traditions, customs and mentality of the Russian people;

- adapt to the independent (without parents, outside the home) life.

Summing up the results of the above, we can say that the system of faculties of preliminary training for foreign citizens is an integral part of the system of training of specialists for foreign countries in the higher educational institutions of our country.However, this element of foreign students training system is crucial, due to a particular specificity of tasks and objectives of the Preparatory Faculty for foreign citizens, as well as of the contingent of students and the special situation in which learning takes place in a foreign language and in a foreign social and cultural environment. 


\section{References}

1. Belov V.A. Professional training for foreign countries in Soviet universities: II half of 1960. - The end of the 1990s.: Abstract. Dissertation of the PhD in history. - M., 2000. - 27 p.

2. Vasilevsky V.L. Training Objectives at the preparatory faculty for foreign citizens / V.L. Vasilevsky // Ways and methods to improve the educational process at the preparatory faculty for foreign citizens: Interuniversity scientific-methodical collection. - Kalinin: 1989. - Pp. 14-16.

3. Golubev A.E. Preparation of national personnel for developing countries in the higher school of the USSR / A.E. Golubev // Contemporary Higher Education. - 1986. - №1. - Pp. 35-41.

4. Zverev N.I. Preuniversity preparation of foreign students in the new environment / N.I. Zverev. // Vestnik CIE Moscow State University, Issue 1, Part 3. - M .: Moscow State University Press, 1997. - Pp. 17-25.

5. Kutuzova G.I. The system of training of students of preparatory faculty to study in high school. / G.I. Kutuzov // Problems of training of national personnel for foreign countries: Proceedings of the International seminarmeeting of deans of preparatory faculties, of December 3-7, 1990. - L.: Lipetsk State Technical University, 1991. - P. 14-16.

6. Rementsov A.N. The concept of additional education of foreign students in Russian universities. / A.N.Rementsov // International scientific-practical conference. - St. Petersburg: SPbSTU, 1999. - Pp. 281 - 285.

7. Rementsov A.N. Additional pre-university training of foreign citizens in the system of continuing professional education in Russia: Diss.... Doctor of Education. / A.N.Rementsov.- M., 2000. - 375 p.

8. Surygin A.I. Pedagogical designing of the system of pre-university training of foreign students / A.I. Surygin. - SPb .: Zlatoust, 2001.-128 p.

9. Titkova N.A. Sociological studies at the preparatory faculty - trend or necessity. / N.A. Titkova // Problems of training of national personnel for foreign countries: Proceedings of the international meeting-seminar of deans of preparatory faculties, on December 3-7, 1990. - L: Lipetsk State Technical University, 1991. - pp. 26-28. 